\title{
Feeding value of defatted cashew kernel as an alternative protein source in broiler diets
}

*Akande, T. O. and Gbadamosi, F. A.

Department of Animal Sciences, Obafemi Awolowo University, Ile-Ife, Nigeria *Corresponding Author:yakandetaiwo@yahoo.com; +2348134543258

Abstract

This study was carried out to determine chemical composition of defatted cashew kernel cake $(C K C)$ and cashew kernel oil (CKO), assess performance characteristics and nutrient digestibility of broiler chickens fed diets containing two grades of CKC. In the study, 210, one-day old Arbor acre broiler chicks which were stabilized on commercial diets $123 \% \mathrm{CP}$ and 2900kcal $/ \mathrm{kgME}$ ) for 2 weeks before introduced to the seven experimental diets were used. The experiment was laid out in a $2 \times 3$ factorial arrangement which consisted of a control treatment without CKC while treatments 2, 3, 4 and 5, 6, 7consisted of $33.33 \%$, $66.67 \%$ and $100 \%$ replacement of groundnut cake (GNC) with grade I and grade II CKC respectively. Digestibility trial was carried out at the end of eighth week of the study. Data on performance attributes and coefficient of nutrient digestibility were collected and analysed using a general linear model of SAS. The results of proximate composition showed no substantial difference in dry matter, crude protein, soluble and insoluble carbohydrate except ether extract. Caloric content in CKC was slightly higher than GNC. Both physical and chemical properties of the defatted cashew oil were similar to that of groundnut. The performance traits measured in terms of body weight gained, total feed intake and feed conversion were significantly $(P<0.05)$ different across the treatments with birds on $C K C$ showing superior performance than birds on GNC diet with $17.72 \%$ and $13.35 \%$ higher $B W G$ in grade I and II respectively. Fat deposition was notably $(P<0.05)$ higher in birds on $C K C$ diets. Digestibility of nutrients indicated that the dry matter, crude protein, ether extract and crude fibre digestibility were significantly $(P<0.05)$ affected across the treatments by the inclusion of $C K C$ in the diets, while the Ash and NFE digestibility were not significantly $(P>0.05)$ influenced. Economically, the use of $C K C$ reduced the heightened cost of production by $9.1 \%$. It can be concluded that grade I CKC could completely and favourably replace GNC in diets of chicken to improve growth, feed efficiency and to reduce the cost of feed per unit egg.

Keywords: Defatted cashew kernel, cashew kernel oil, chemical constituent, performance, digestibility, broilers

\section{Introduction}

Cashew (Anarcardium occidentale L.) are cultivated mainly in southern part of Nigeria and are becoming a wellestablished activity for the production of the kernel. Cashew ranks third in world production of edible nuts with the estimated global production of 4,439,960 metric tons and Nigeria, the highest producer in Africaranked second on a global scale (FAO, 2016). FAO records also show that both production and yield of groundnut, have continue to drop since 2006 in Nigeria whereas cashew nut has continued to enjoy a consistent rise in production.

The growing interest in cashew may be partly ascribed to the supposed dual role of the kennel which have found application in the confectionery industry as an important source of lipids and protein (Yahaya et al., 2012). Cashew nut yields two "Oils" one of these, found between the seed coat or pericarp and the nuts, is called the Cashew Nut Shell Liquid (CNSL) which has found 


\section{Feeding value of defatted cashew kernel}

wide applications in chemical industries and as reliable petrochemical feedstock (Dosunmu et al., 1995; Taiwo, 2000). The second type is edible oil found in the kernel of the cashew nut named cashew kernel oil (CKO). It contains high proportion of unsaturated fatty acids and finds uses in food, medicine and cosmetics industries (Achal, 2002; Akpan et al., 2004; Abitogun and Borokini, 2009; Idah et al., 2014). Despite the values of these oils hitherto, there is no evidence of the commercial production in Nigeria, which invariably yield another important product, cashew kernel cake.

The nutritional values of cashew kernel cake have long been recognized (Fetuga et al., 1974). Reports from literature have indicated that these cashew kernels and particularly the rejects have been applied as animal feed (Odunsi 2002; Ojewola et al., 2004; Akande et al., 2015; Carlos et al., 2015). Industrially, about 30-35\% cashew kernel is often discarded either as broken or scorched kernels during processing for failure to meet export or local requirement grade. Despite the positive recommendation in the available literature and over a decade of reports on suitability of cashew kernel as feed for farm animals, no single feed mill in Nigeria has cashew kernel meal as part of their feed stock, most of the nuts are packaged for export or processed as snacks.

The subject of feed resources and their availability represents the most compelling task facing producers and scientists in poultry industry. The attempt to mitigate high cost of feed has prompted the continuous search for additional feedstuffs. This search for solutions is hinged on the concept to achieve sustainability based on the use of indigenous resources. Groundnut and soybean remain the principal sources of plant protein in diets of poultry and this has imparted negatively on the turn over from poultry business because of extremes of cost and stiff competition between human and animal associated with these protein sources. Besides, the production of these crops can no longer cope with increasing population and expanding poultry industry that depend extensively on compounded rations (Longe, 2006). There is the need to search for suitable alternatives to complement these conventional feed ingredients. Different grades of cashew kernel reject which are industrially accessible could be suitable alternative protein sources; however these grades have not been differently tested to indicate their value in diets of broiler chickens. This study intends to compare two different grades of CKC as replacement for GNC.

\section{Experimental station}

The experiment was carried out at the Poultry Unit, Teaching and Research Farm, Obafemi Awolowo University Ile- Ife, Osun State, Nigeria.

\section{Collection and processing of test ingredients}

One hundred and forty kilogram each of grade I and grade II cashew kernel reject was purchased from Vallency Cashew Processing LTD Ibafo, Ogun State. Both grades were milled, loaded into muslin cloth and mechanically pressed using an oil screw press machine for 6 hours per loading to facilitate oil extraction. Both oil and cake were preserved for subsequent use and analysis.

\section{Experimental animals and management}

A total of 210 one-day old Abor Acre broiler chicks were procured from a reputable farm for this study. The chicks were stabilized for two weeks on commercial diets $23 \% \mathrm{CP}$ and $3000 \mathrm{kcal} / \mathrm{kg}$. All routine vaccination and medications were applied. Birds were weighed and randomly allotted to the seven dietary treatments. Feed and water were offered $a d$ 


\section{Akande and Gbadamosi}

libitum for six weeks in a deep litter house.

\section{Experimental diets}

Seven experimental diets were formulated for the study. The gross composition of experimental diets for broiler finisher phase is as shown in Table 1 below.

Table 1: Experimental diets for broiler finisher

\begin{tabular}{|c|c|c|c|c|c|c|c|}
\hline \multirow[b]{2}{*}{ Ingredient , \% } & \multirow{2}{*}{$\begin{array}{c}\text { Control } \\
0 \%\end{array}$} & \multicolumn{2}{|r|}{ Grade I } & \multirow[b]{2}{*}{$100 \%$} & \multicolumn{2}{|r|}{ Grade II } & \multirow[b]{2}{*}{$100 \%$} \\
\hline & & $33.33 \%$ & $66.67 \%$ & & $33.33 \%$ & $66.67 \%$ & \\
\hline Maize & 60.00 & 57.50 & 55.00 & 53.00 & 57.50 & 55.00 & 53.00 \\
\hline Cashew kernel cake & - & 12.50 & 25.00 & 37.00 & 12.50 & 25.00 & 37.00 \\
\hline Ground nut cake & 30.00 & 20.00 & 10.00 & 0.00 & 20.00 & 10.00 & 0.00 \\
\hline Fixed Ingredient & 10.00 & 10.00 & 10.00 & 10.00 & 10.00 & 10.00 & 10.00 \\
\hline Total & 100.00 & 100.00 & 100.00 & 100.00 & 100.00 & 100.00 & 100.00 \\
\hline \multicolumn{8}{|l|}{ Calculated Analysis \% } \\
\hline Crud Protein & 21.70 & 21.50 & 21.35 & 21.20 & 21.50 & 21.35 & 21.20 \\
\hline $\begin{array}{l}\text { Metabolizable Energy } \\
(\mathrm{kcal} / \mathrm{kg})\end{array}$ & 3005.81 & 3012.82 & 3004.95 & 3000.31 & 3012.82 & 3004.95 & 3000.31 \\
\hline Calcium & 1.24 & 1.35 & 1.28 & 1.26 & 1.35 & 1.28 & 1.26 \\
\hline Phosphorus & 0.45 & 0.48 & 0.44 & 0.41 & 0.48 & 0.44 & 0.41 \\
\hline Lysine & 0.90 & 0.77 & 0.68 & 1.63 & 0.77 & 0.68 & 1.63 \\
\hline Methionine & 0.59 & 0.55 & 0.49 & 0.44 & 0.55 & 0.49 & 0.44 \\
\hline Crude Fibre & 3.11 & 2.51 & 1.98 & 1.52 & 2.51 & 1.98 & 1.52 \\
\hline
\end{tabular}

\section{Data collection}

Samples of cashew kernel cake (CKC) and cashew kernel oil (CKO) were screened for proximate composition according to procedure of AOAC (2009) and physicchemical properties respectively. On weekly basis, measured feed was given to experimental birds and at the end of each week, feed remnant was weighed back. Feed intake was then calculated by the difference. Records of weight gain, feed intake, and feed to weight gain ratio were kept on treatment basis. The economic implication was determined by current prices of feed ingredients. At eighth week, a bird per replicate was randomly selected and kept in metabolic cage equipped with watering and feeding facilities for faecal collection. Feed intake and left over were measured daily. The birds were allowed four days of acclimatization period after which they were starved for 12 hours to clear the gut of previous meal, followed by 3 days of feeding and total faecal collection. Fresh weight of total faeces voided was collected, weighed and oven dried separately at $60^{\circ} \mathrm{C}$ for 24 hours then mixed, milled and representative samples were taken for proximate analysis as described under chemical analysis of samples. The proximate composition of the diets and faeces were used to calculate the apparent nutrient digestibility of individual diet

\section{Statistical analysis}

Data collected were subjected to analysis of variance using the procedure of SAS (2009) while significant differences in means were separated using Duncan's multiple range tests.

\section{Results and discussion}

Proximate composition of the defatted cashew kernel and physico-chemical properties of the oil

The proximate composition of both grades of defatted cashew kernel and physicochemical properties of the oil in comparison with groundnut is as shown in Table 2. The results of chemical screening of both grades have shown that their 


\section{Feeding value of defatted cashew kernel}

nutrient profilesare quite suitableand comparable to groundnut cake and were adequate to meet the requirement of broilers as demonstrated in the performance traits. However, higher ether extract showed that extraction method of oil from kernel need to be improved upon. Notably, the higher crude fibre in grade II may not support adequate utilization by young chicks. The determined nutrient content of the DCK obtained in this study was slightly at variance with the findings of Fetuga et al., (1974) but closely related to the findings of Ojewola et al., (2004). Various factors ranging from the processing method, length of storage and varietal difference could be responsible for such variation.
Similarly, both physical and chemical properties of the defatted cashew oil were similar to that of groundnut oil suggesting the cooking suitability of the oil. Flash and Fire Point show that the sample oil show great response to the heat and flame at elevating temperature. Low peroxide and acid value coupled with higher saponification may provide some edge over groundnut oil as there will be low level of hydrolytic activity in the oil. According to Demian (1990), acid values are used to measure the extent to which glycerides in the oil has been decomposed by lipase and other physical factors such as light and heat. The higher the saponification numbers of the oil, the more soluble the soap that can be made from it (Alyas et al., 2006).

Table 2: Proximate composition of cashew kernel cake (CKC) and physico-chemical properties of cashew kernel oil (CKO)

\begin{tabular}{|c|c|c|c|}
\hline \multirow{2}{*}{$\begin{array}{l}\text { Parameters } \\
\text { Proximate, \% }\end{array}$} & \multicolumn{2}{|c|}{ Cashew (CKC) } & \multirow[t]{2}{*}{ Groundnut (GNC) } \\
\hline & Grade I & Grade II & \\
\hline Dry Matter & 92.03 & 92.49 & - \\
\hline Crude Fibre & 7.05 & 10.30 & 6.96 \\
\hline Crude Protein & 35.00 & 33.95 & 42.10 \\
\hline Ether Extract & 17.40 & 18.10 & 5.03 \\
\hline Nitrogen Free Extract & 36.25 & 35.15 & 41.00 \\
\hline Ash & 4.30 & 2.50 & 3.01 \\
\hline $\mathrm{GE}(\mathrm{Kcal} / \mathrm{kg})$ & 4970 & 4942 & ${ }^{+} 4588.80$ \\
\hline *Physical properties & Cashew oil & & Groundnut oil \\
\hline Cloud point & -7 & & -5 \\
\hline Pour point & -11 & & -3 \\
\hline Flash point & 218 & & 249.1 \\
\hline $\begin{array}{l}\text { Fire point } \\
* * \text { Chemical Properties }\end{array}$ & 244 & & 255 \\
\hline Acid value & 1.26 & & 4.4 \\
\hline Saponification & 180 & & 189 \\
\hline Peroxide & 67 & & 1.97 \\
\hline Refractive index & 1.4 & & 1.46 \\
\hline Specifi gravity & 0.97 & & 0.91 \\
\hline Viscocity" $40^{\circ} \mathrm{C}$ & 15.2 & & 0.918 \\
\hline Colout TCU & 5.8 & & - \\
\hline
\end{tabular}

\section{Performance of broiler chicken fed two} grades of cashew kernel cake (CKC)

Table 3 showed the performance traits of broiler chickens fed two grades of DCK at varying inclusion levels. The performance traits measured showed significant $(\mathrm{P}<0.05)$ differences across the treatments. Nevertheless, the results reveal that there were no significant interaction effect in terms of inclusion level and grades of $\mathrm{CKC}$ 


\section{Akande and Gbadamosi}

across all the treatments. The BWG of birds on both grade I and II CKC had superior performance than birds on the control diet with $17.72 \%$ and $13.35 \%$ increase, respectively. Conversely, an earlier experiment involving broiler chickens fed different levels of reject cashew kernels showed that there were no significant $(\mathrm{P}>$ 0.05) differences across treatments with respect to all the parameters tested except in the cost of feeding (Oddoye, et al., (2012).
Feed conversion was significantly better in birds fed grade I CKC compared to birds on grade $2 \mathrm{CKC}$ and control diets. This was reflected in better utilization of DCRM than in birds fed the control diet. In lieu of the total feed intake TFI, it was observed that inclusion levels of CKC in the diets did not follow a definite pattern, meaning that different inclusion levels of CKChad no deleterious effect on performance traits of birds. No mortality was recorded throughout the experimental period.

Table 3: Performance of broilers fed two grades of cashew kernel cake at varying inclusion levels

\begin{tabular}{|c|c|c|c|c|c|c|c|c|c|c|c|}
\hline \multirow{3}{*}{$\begin{array}{l}\text { Parameter } \\
\text { Treatment } \\
\text { Replacement }\end{array}$} & \multirow{3}{*}{$\begin{array}{c}\text { Control } \\
\text { T1 } \\
0 \%\end{array}$} & \multicolumn{3}{|c|}{ Grade I } & \multicolumn{3}{|c|}{ Grade II } & \multirow{2}{*}{\multicolumn{4}{|c|}{ P-Value }} \\
\hline & & T2 & T3 & T4 & T5 & T6 & T7 & & & & \\
\hline & & $33.33 \%$ & $66.67 \%$ & $100 \%$ & $33.33 \%$ & $66.67 \%$ & $100 \%$ & SEM & G & L & Gx L \\
\hline IBW(g/bird) & 236.11 & 236.11 & 238.89 & 230.56 & 238.89 & 230.50 & 233.33 & 1.24 & 0.86 & 0.25 & 0.16 \\
\hline FBW(g/bird) & 2026.50 & 2280.50 & 2431.00 & 2521.90 & 2311.00 & 2339.70 & 2251.60 & 37.56 & 0.01 & 0.05 & 0.25 \\
\hline $\mathrm{BWG}(\mathrm{g} / \mathrm{b})$ & 1790.40 & 2044.40 & 2192.10 & 2291.30 & 2072.10 & 2109.20 & 2017.40 & 37.95 & 0.01 & 0.04 & 0.25 \\
\hline TFI $(\mathrm{g})$ & 4779.80 & 4765.30 & 4942.60 & 4977.60 & 4923.90 & 5217.90 & 5173.60 & 44.14 & 0.04 & 0.02 & 0.76 \\
\hline $\mathrm{DFI}(\mathrm{g} / \mathrm{b} / \mathrm{d})$ & 113.81 & 113.46 & 117.68 & 118.51 & 117.24 & 124.24 & 123.18 & 1.05 & 0.04 & 0.02 & 0.76 \\
\hline FCR & 2.67 & 2.35 & 2.26 & 2.17 & 2.38 & 2.48 & 2.59 & 0.04 & 0.01 & 0.05 & 0.21 \\
\hline Abd. fat & 0.62 & 1.06 & 1.74 & 2.05 & 1.17 & 1.88 & 2.27 & 0.14 & 0.01 & 0.03 & 0.04 \\
\hline Mortality & 0 & 0 & 0 & 0 & 0 & 0 & 0 & - & - & - & - \\
\hline
\end{tabular}

Apparent nutrients digestibility of defatted cashew kernels in broiler chickens diets

Table 4 shows the apparent nutrient digestibility of two grades of $\mathrm{CKC}$ at varying inclusion levels in broiler chicken diets. Results of this study indicated that the dry matter (DM), crude protein (CP), ether extract (EE) and crude fibre digestibility were significantly $(\mathrm{P}<0.05)$ affected across the treatments by the inclusion of CKC in the diets, while the ash and NFE digestibility were not significantly influenced $(\mathrm{P}>0.05)$. The result also revealed that there was no interaction effect between the inclusion level and grades of CKC across all the treatments. Digestibility of ether extract was noticeably increased linearly with increased levels of inclusion of CKC which implies that the fat in cashew kernel meal is vastly digestible by broiler chickens. This fact is in close agreement with the findings of Ogungbenro et al., (2013) who reported a linear increase in ether extract digestibility of turkey poults with an increase level of cashew nut meal in the diets. The upward increase $(p>0.05)$ in the $\mathrm{CP}$ and overall DM digestibility with higher inclusion of DCK across the treatments is also a pointer that could partly account for the observed better performance in birds fed both grades of CKC.

Although, birds on both grade of DCK had higher digestibility coefficients than the control, lower testa volume (visual appraisal) contained in grade I CKC compared to grade II may be an influencing factor for the difference observed in the two groups. Nonetheless, birds on both grades of $\mathrm{CKC}$ efficiently utilize the nutrients in their diets which demonstrate the nutritional adequacy or suitability of $\mathrm{CKC}$ as plant protein substitute for GNC in broiler chickens' diet. It could also be induced that there were no notable anti metabolic compounds (not determined) in 


\section{Feeding value of defatted cashew kernel}

both grades of CKC used that is capable of impeding the nutrient digestion of cashew kernel meal.

\section{Cost benefits of using DCK in diets of broilers}

As at the time of this study, cost per kilogram of GNC, CKC grade I and grade II costs fl 180, fl 100 and fl 85.719 (Nigeria Naira), respectively. From Table 4, cost of feed per kilogram for diets containing both grades of CKC were substantially lower with $12.43 \%$ and $15.83 \%$ reduction than that of the control diets. To produce 1 ton of broiler feed using $\mathrm{GNC}$ and $\mathrm{CKC}$, the farmer will expend about fl 185,000 and fl 165,000 respectively. This implies that the farmer will be able to save as much as fl 20,000 from every tonnage of feed produced using CKC. Farmers will be able to cut about $9.1 \%$ cost with the use of CKC in place of GNC in broiler diet.

Table 4: Apparent nutrients digestibility of two grades of cashew kernel cake at varying inclusion levels in diets of broiler chicken

\begin{tabular}{|c|c|c|c|c|c|c|c|c|c|c|c|}
\hline \multirow[b]{2}{*}{ Levels } & \multicolumn{2}{|l|}{ Control } & \multirow{2}{*}{\multicolumn{2}{|c|}{$\begin{array}{l}\text { Grade I } \\
66.67 \%\end{array}$}} & \multicolumn{3}{|c|}{ Grade II } & & \multicolumn{3}{|c|}{ P- Values } \\
\hline & $0 \%$ & $33.33 \%$ & & & $33.33 \%$ & 66.67 & & & & & \\
\hline & & & & & & & & & & & \\
\hline Nutilemis, 70 & 11 & 12 & 15 & 14 & 15 & 10 & & SEIVI & 0 & L & UXL \\
\hline Dry Matter & 80.70 & 85.00 & 87.84 & 89.12 & 80.76 & 83.62 & 83.58 & 0.94 & 0.03 & 0.26 & 0.15 \\
\hline Ether Extract & 78.45 & 86.10 & 89.22 & 90.29 & 83.95 & 88.73 & 88.89 & 0.94 & 0.01 & 0.01 & 0.22 \\
\hline Crude Fibre & 48.20 & 53.48 & 51.02 & 51.45 & 54.09 & 48.37 & 39.04 & 1.31 & 0.01 & 0.01 & 0.19 \\
\hline Ash & 53.45 & 57.48 & 55.71 & 56.66 & 54.38 & 56.26 & 53.27 & 0.80 & 0.79 & 0.87 & 0.71 \\
\hline Crude Protein & 70.04 & 78.81 & 80.11 & 82.01 & 71.65 & 70.35 & 68.74 & 1.55 & 0.04 & 0.92 & 0.82 \\
\hline NFE & 84.20 & 85.76 & 86.05 & 87.04 & 84.80 & 84.82 & 78.79 & 0.77 & 0.07 & 0.14 & 0.18 \\
\hline
\end{tabular}

Table 5: Economic implications of feeding broilers with diets containing two grades of CKC

\begin{tabular}{llllll}
\hline Parameters & Control & Grade I & Grade II & SEM & P-Value \\
\hline BWG(g/bird) & $1790.42^{\mathrm{b}}$ & $2175.94^{\mathrm{a}}$ & $2066.85^{\mathrm{a}}$ & 37.95 & 0.01 \\
TFI, g & $4780^{\mathrm{b}}$ & $4910^{\mathrm{b}}$ & $5110^{\mathrm{a}}$ & 44.14 & 0.04 \\
Cost/kg of test ingredients (fl ) & $180.00^{\mathrm{a}}$ & $100.00^{\mathrm{b}}$ & $85.71^{\mathrm{c}}$ & 20.81 & 0.04 \\
Cost of feed / kg (fl ) & $185.64^{\mathrm{a}}$ & $165.11^{\mathrm{b}}$ & $160.21^{\mathrm{b}}$ & 25.99 & 0.05 \\
Cost of feed consumed / bird (fl ) & $884.30^{\mathrm{a}}$ & $810.69^{\mathrm{c}}$ & $818.67^{\mathrm{b}}$ & 15.88 & 0.04 \\
\hline$a, b, c$ Means within the same row with different superscripts differs significantly $(p<0.05)$ & & &
\end{tabular}

$a, b, c:$ Means within the same row with different superscripts differs significantly $(p<0.05)$

\section{Conclusion}

Defatted cashew kernel was nutritionally superior to GNC. It adequately supportrequirement of broiler chickens for growth with overall better nutrient utilization at lower cost. The edible oil obtained in addition to cake for animal feed is suggestive of a prospective enterprise in cashew kernel processing industry in Nigeria.

\section{References}

Abitogun, A. S. and Borokini, F. B. 2009. Physicochemical Parameters and Fatty Acid Composition of $\mathrm{C}$ a s h e w $\quad \mathrm{N} \mathrm{u} \mathrm{t}$
(Anacardiumoccidentale) Oil.Journal of Research National Development, 7(2)

Achal, L. W., Namhong, T., Yu, C. H. and Chen, H. H. 2002. Impact of roasting on changes in composition and quality of cashew nut (Anacardium occidentale) oil. International Food Research Journal 23(3): 986-991.

Akande, T. O., Akinwumi, A. O. and Abegunde, T. O. 2015. Cashew rejects meal in diet of laying chickens: nutritional and economic suitability. Journal of 


\section{Akande and Gbadamosi}

Animal Science and Technology 57:17.

Alyas, S. A., Abdulah, A. and Idris, N. A. J. 2006. Oil Palm Research (Special Issue), 2006. pp. 99102.

AOAC 2009. Official methods of analysis.18th edition. Published by the Association of Official Analytical Chemists; Arlington, Virginia.

Briggs T. and Victor J. 2014. Determination of suitability of groundnut oil as a hydraulic fluid European Journal of Mechanical Engineering Research 1(1):1-13

Carlos, E. B. 2015. Cashew Nut Meal in the Feeding of Brown Laying Hens. Article in Ciênciae Agrotecnologia.

Demian, M. J. 1990. Principles of Food Chemistry. 2nd Ed. Van Nostrond Reinhold Intl Company Limited, London, England, 1990.pp: 37-38

Dosunmu, M. I., and Ochu, C. 1995. Physicochemical properties and fatty acid composition of lipids extracted from some Nigerian fruits and seeds. Global Journal of Pure and Applied Sciences, 1(1/2), $45-50$.

FAO 2016. Food and Agriculture Organization of the United Nations. Statistics division http://www.fao.org/statistics/en/

Fetuga B. L., Babatunde, G. M. and O y e n u g a , V. A . 1974. Composition and nutritive value of cashew nut to the rat. Journal of Agriculture and food chemistry, 22: 678-682.

Idah, P. A, Simeon M. I., Mohammed, M.

A. 2014. Extraction and Characterization of Cashew Nut (Anacardiumoccidentale) Oil and Cashew Shell Liquid Oil Ac ademic Research International Vol. 5(3).

Oddoye, E. O., Asiedu, B., Kwenin, W. k., and Johnson. V. 2013. Broiler performance on starter diets containing different levels of rejected cashew kernel meal. Anim. Vet. Sci. 3 (7)221-224.

Odunsi, A. A. 2002. Effect of feeding reject cashew kernel meal on pre and early laying performance of pullet.Arch. Zootec., 51: 423429.

Ogungbenro, S. D. ; Raji, M. O. ; Bamgbose, A. M. ; Oso, A. O. ; Sogunle, O. M., 2013.Effect of replacement of cashew nut meal-maize offal with maize on the performance of turkey poults.Int. Journal of Agric. Biosci., 2 (4): 164-167.

Ojewola, G. S. Okoye, F. C. Agbakuru, I. 2004. Replacement value of cashew-nut meal forsoyabean meal in finishing broiler chickens.Intl Journal of Poult. Sci., 3 (8): 513-516.

Pandurangan M. K., Murugesan S. and Gajivaradhan P. 2014. Physicochemical properties of groundnut oil and their blends with other vegetable oilsJournal of Chemical and Pharmaceutical Research 6(8):60-66

Yahaya A. T., Taiwo O., Shittu T. R., Yahaya L. E., Jayeola, C.O. 2012. Investment in Cashew Kernel Oil Production: Cost and Return Analysis of Three Processing Methods. Economics and Statistics Unit, Cocoa Research Institute of Nigeria, PMB 5244, Ibadan.

Received: $25^{\text {th }}$ July, 2018

Accepted: $21^{\text {st }}$ December, 2018 